\title{
Discussion on Strategies of Development and Application of Human Resources
}

\author{
Hong Fang \\ School of Inter-cultural Studies of Jiangxi Normal University \\ Nanchang 330022, Jiangxi, China \\ E-mail: fh8736197@126.com \\ Hongmin Zhou \\ Institute of Teacher Education of jiangxi normal university \\ Nanchang 330022, Jiangxi, China
}

\begin{abstract}
Establishment of a great power with human resources is one of the major strategies in China. To strengthen development and application of human resources is an important task China is currently faced up with. In this article, the author attempts to discuss strategies of development and application of human resources from several aspects, such as education, market, enterprises and the government, etc.
\end{abstract}

Keywords: Human resources, Development and application, Education, Talents, Countermeasures

To develop education with priority and to establish a great power with strong human resources is the significant strategic decision made by the Party Central Committee to further carry out the strategy of rejuvenating the country through science and education and the strategy of reinvigorating China through human resource development in a new historical stage. Human resource is the first source for development of a country, and establishment of human resources has become a key factor in realizing development of China.

Human resource refers to the total population with the competence of labour which can promote development of the entire economy and society. Generally speaking, development and application of human resources in China is still at a low level, incomprehensive and imbalanced, as a result of which supply of human resources with high quality is inadequate. There also exist some problems to be dealt with in the aspect of education which is the major channel for human resource training. For example, the aspect of basic education is weak, quality of higher education, adult education and vocational and technical education is open for improvement, and financial educational expenditure is open for increase, etc. The issue of human resource is connected to the rise and decline and the destiny of a country. How to sufficiently and effectively strengthen development and application of human resource, transform the quantity of population into advantages of human resource, and encourage China to switch from a country with large population into a great country with strong human resources is an important issue encountered at present. Therefore, we should attempt to discuss and strengthen strategies about development and application of human resources from several aspects, such as education, market, enterprises and the government, etc.

\section{To intensify strategies of human resources in which education is the subject}

\subsection{To adjust the structure of talent training, strengthen practical aspects and improve education quality}

Economic construction of China is badly in need of a large majority of technical talents with professional knowledge. Starting from actual requirements of economic construction, we should make an adjustment on design of professional courses, change training of research-based and communication-based talents in the past into training of skill-based and science-and-technology-based talents, so as to form a gradient pattern of talents and satisfy demands of different industries and different regions on talents of different levels. In terms of teaching schedule, we should change the status quo of weak practical aspects and vigorously intensify each practical teaching process; in terms of the structure of the teaching team, we should change the situation of inadequate application-based talents, establish a teaching team 
centered by teaching and a teaching and research team centered by scientific research, vigorously development scientific and technical industries and produce a benign system with combination of teaching, scientific research and production.

\subsection{To rationally optimize scale and pattern of schools at all levels to improve the overall efficiency of running a school}

In recent years, according to development trend of the population of entering the school at a school age, and through distribution of elementary and secondary schools, especially reconfiguration and adjustment on distribution networks of rural elementary and secondary schools, we have merged those elementary and secondary schools seriously inadequate in sources of students, have optimized allocation of teachers and have improved teaching quality to a large extent. Starting from actual requirements of the personnel market, and according to their own conditions, those universities and technical secondary schools with low application rate of education resources take measures of large-scale mergence, etc, and readjust design of some departments and majors, which gradually enables those universities and colleges to go towards appropriateness and enables their discipline structure to go toward rationality.

\subsection{To strengthen vocational education}

Making a general survey of any economically powerful nation in the world, it is not difficult to discover, their developmental history has indicated vocational education and in-job training is the fundamental channel to cultivate industrial main forces with high quality. Training and education of laborers, and their skill development and improvement are significant factors to promote sustained and rapid growth of the economy.

Influenced by the idea of traditional education, to enter colleges and universities has become a general target of those who pursue learning, and vocational education has become a weak aspect in the educational structure. Both the supportive strength of the government education budget and such aspects as materials and facilities of training employees have always been in a laggard state. Therefore, we should adjust educational structure, regard vocational education as focus of education and further enlarge investment strength and training strength of vocational education so as to satisfy demands of a province on such a sort of talents. We can adopt corresponding measures to strengthen strength of publicity, change the concept of thoughts and intensify recognition of the whole society in vocational education; we should enlarge investment in vocational education, provide support in terms of policies, and lead social investment into vocational education on the basis of educational expenditure investment by the government; we should keep abreast with the personnel market, and adjust in good time design of majors and the structure of talent training; we should impart skills, guarantee teaching quality, strengthen practice and intensify innovational consciousness and market competition consciousness so as to satisfy demands of the society on all sorts of skilled talents.

\section{To try to increase the proportion of the national financial educational expenditure}

\subsection{To ensure strength of expenditure investment and to realize diversification of the subject of investment}

Sufficient education budget investment is the precondition to guarantee high quality development of education. In China, the government is the major source for educational investment, and the proportion of the total amount of financial educational expenditure to the domestic GDP is $4 \%$ lower than the target. Therefore, on one hand, we should attempt to increase the proportion of financial educational expenditure to the total financial expenditure in the future, and enlarge the total scale of educational investment; on the other hand, we should broaden sources and channels of educational budget, realize the multi-channel educational investment mode in which the government financial educational expenditure is the major channel with the diversified channels of investment from social associations, enterprises, schools, collectivity and individuals, and also clearly partition obligations of the central and local financial educational expenditure. The direction of the national financial educational expenditure places particular stress on basic educational investment, but for non-compulsory education, a mechanism should be gradually established that is rationally shared by the government, the society, the family and individuals. However, for higher education, the principle of equal value exchange is adopted, in which individuals should burden corresponding part of educational expenses and they are the direct beneficiary of education. Due to high higher education cost, the system of school loan for university students should be gradually established and made perfect, which, on one hand, may resolve the problem of having difficulties in paying for tuition fee for university students from poor families, and on the other hand, may realize circulation of assets in the education field and relieve the contradiction of tight educational budget to a certain extent, which in turn may relieve the burden of the national financial educational expenditure and increase the benefit.

The high quality of corporate employees originates from education. Therefore, in addition to investment by the government and residents themselves, the enterprise is also the beneficiary of educational investment, and should also assume its social responsibility for education. Thus, the government should adopt preferential policies, encourage enterprises to invest and set up schools, and encourage alliance between schools and enterprises. For example, they can establish educational funds, donate for schools at all levels and set up scholarship at schools of all levels, etc. All the above can not only enlarge sources and channels of educational budget, but also can reserve talents for enterprises. 


\subsection{To optimize the structure and to strengthen management of educational budget}

The economic structure decides the educational structure, which in turn affects adjustment and optimization of the economic structure, whereas the educational structure determines the structure of educational expenditure. Therefore, establishment of scientific and rational educational expenditure distribution and application structure is the necessary condition to increase the benefit of educational expenditure.

Considering the levels of education, educational budget should be inclined to basic education, and should enable the proportion of educational expenditure at schools of all levels to go towards rationalization. Development of basic education determines the overall quality of a nation or a region, and is the fundamental scale for the overall level of human resources in a society, so it is in a fundamental status. Considering the conditions of China in which there is a large population base, a large quantity of school-age population, unstable educational expenditure in grass-root town and village elementary and secondary schools, we should appropriately increase the extent of investment in basic education in order to ensure popularity rate of basic education, especially the proportion of educational expenditure for the nine years of compulsory education.

\section{To perfect the market of human capital and to strengthen management of human resources}

The primary targets of macro-control in the field of labor are, on one hand, the total quantity and structure of supply and demand of labor force, and on the other hand, cost of labor force and salary level. The macro-control that is at a developmental stage of the labor force market, is not only aimed at activities in the market, but also includes regulation and control made up for imperfections in the market, also including some direct control over enterprises.

\subsection{To formulate the plan of development and application of labor force resources}

The plan of human resource development and application includes development of education and training, improvement of labor force quality and improvement of the structure of labor r. According to prediction on economic development, we should plan approaches and methods of application of labor force, guide adjustment of employment structure, improve employment level, reduce waste of human resources and strengthen the organization and plan of investment of assets used for development of human resources. "Bottleneck" in development of human resources is vocational and technical training, whereas development direction of vocational training is to form open and market-oriented vocational training system, socialized management system of occupation skill appraisal, vocational training legislation and administrative laws and regulations system. All the above should be reflected in the plan of development of human resources. We should reinforce the strategic status and important role of human resource development in the national economy and social development and list the plan of development and application of labor resources into the plan of the entire national economy and social development.

\subsection{To establish the system of minimum labor standard so as to provide evidence for the country to intervene in the market of labor force}

The minimum labor standard system is the basic requirement to standardize labor conditions, including minimum wage, maximum time standard, minimum requirement of vocational training and minimum requirement of security and sanitation, etc. Establishment of the minimum labor standard system is not only positive intervening measure to the market of labor force, but also provides indispensable evidence for supervision on labor.

\subsection{To perfect the running order of labor market}

We should bring the movement-oriented effect of market information into full play and establish a price-oriented mechanism with flow of talented people. We should bring into play the functions of the personnel market, and make standardized investigation, collection, classification and release of the market price of all sorts of talents regularly or in time. We should in good time release information about the market price of all sorts of talents with reliability and authority, and form a scientific and sound mechanism with orientation of talent allocation and an average salary mechanism with the orientation of average price of the market. As for issues that emerge in development of the personnel market, we should immediately give guidance, coordination and management, and use legal, economic and necessary administrative means to ensure the positive role of the personnel market in the aspect of leading flow of talents.

\section{To intensify introduction of talents and to reinforce their innovative competence}

\subsection{To strengthen guidance and management of policies and to create good environment for introduction of talents}

From the perspective of the natural environment, implementation of establishment of humanistic environment and improvement of the ecological environment can provide laborers with good working and living environment. according to the theory of the second stage of Growth Pole Theory by Perroux, when "polarization" of human capital is centralized to a certain degree, then the effect of "polarization" will transfer to the effect of "drip" as a result of spatial constraints and influences of such factors as increase of cost and transaction expense. Speed of the transfer is determined by gap between economic development and external environment of the central area and surrounding areas. 
We should continue to strengthen establishment of the humanistic environment and ecological environment, narrow gap between different areas, save opportunity costs of flow of talents and create good external conditions for introduction of talents.

From the perspective of system, we should reform the system of talent employment, realize the Each-Member Contract Employment System of talent employment, promote the contract of relationship between subjects of talent supply and demand, enlarge the scope of the contract system of talent employment from part of enterprises to all enterprises and from enterprise units to public institutions, so as to ensure that constraints of subjects of staff relation can go towards of track of contract and legalization. To deepen reform of urban social security system, establish and perfect rural social security system and gradually realize separation of employment, social welfare and social security. To attach great importance to speeding up establishment of endowment insurance, unemployment insurance, medical insurance and reform of housing system, set up social unemployment system through social overall planning, gradually realize commercialization of housing, reform personal information records and household registration system and alleviate worries behind caused by flow of talents, so as to ensure that flow of talents will not be influenced by housing, household registration and archives, etc, and to enable all sorts of talents to make an independent option on a fair, equal and competitive condition.

\subsection{To establish the strategy of reinvigorating China through human resource development and to promote scientific innovation in a comprehensive way}

To reinforce the competitiveness as a breakthrough, to simultaneously support cultivation of new and high technology industries and renovation of traditional industries with new and high technology industries, simultaneously support scientific innovation and conversion of scientific achievements, establish sound technical innovation system based on economic construction and structural adjustment, bring into full play potentials of high-tech talents, continuously strengthen vigor of scientific development and improve rate of contribution of scientific progress to economic growth. To intensify treatment and development of important fields and critical technology, strengthen the subject position of corporate technical innovation and improve technical innovation competence of enterprises in a comprehensive way. Large-and-middle-sized enterprises should enlarge investment in technical development, set up technical research and development center for research and development of leading products with proprietary intellectual property rights, add to technical reserve and strengthen developmental potential of enterprises. Construction of research and development bases should be made perfect on the basis of universities and scientific research institutions. A batch of science and technology service agents should be development, for which the supportive vigor should be intensified in terms of policies and assets so as to industrialization of scientific achievements. In those technical fields with comparative advantages, great industrial relevancy degree and optimal market prospect, which are in favour of resolving important and difficult issues in economic and social development, attempt should be made with concentration for technical development and treatment. New breakthrough should be made in development of high and new technical industries, cultivation of leading industries, renovation of traditional industries, promotion of agricultural science, urban construction and environmental protection, and the fields of new materials.

\section{To perfect functions of the labor department of the government and to strengthen macro-control}

\subsection{To standardize guidance so as to create conditions for development and running of the labor force market}

\subsubsection{To intensify functions of labor department and to improve its consciousness of service}

In addition to a sound and perfect social service system, management function of the labor department should also reflect the spirit of service. The primary task of grass-root municipal and county labor departments is to provide service for employing units and laborers, such as, occupational counseling, occupational introduction, information guidance and management of retired persons, etc. In order to develop service industry, the labor department should set up intermediary organizations and service entities adapting to demands of the market, form a network according to the requirements of professionalization, industrialization and integration under the direction of labor administrative organs, and offer high-quality service for both of the two parties. Correspondingly, the labor department should make great efforts to train a labor cadre team proficient in knowledge of market and familiar with skills of market running. Then, labor supervision should be comprehensively strengthened, which is the primary aspect for the labor department to changes functions, and supervision on functions of the labor department should be timely and effective.

\subsubsection{To provide asset support for construction and running of the labor force market}

In the process of cultivating the labor force market, reinforcing basic construction of the market and perfecting service means, there should be stable assets as conditions of support and insurance. In order to generate normal sources and channels for investment of assets and resolve sources of assets, there are mainly the following three approaches: central and local financial allocation and self-financing of the labor department. As for assets invested, the first step should complete the following projects: (1) Rational arrangement of employment agency, vocational training center, social security center and self-help production base above the level of county, so as to attempt to set up all sorts of service 
agencies in each county with one occasion and certain working means; (2) Allocation of establishment strength in various social service agencies and training of employees to improve their overall quality; (3) Allocation of equipment in all sorts of social agencies so as to complete the network project of employment agency and social security administration system. In addition, On the basis of establishing the macro-control system, quite a large amount of assets are required for investment, including establishment of information system and supervision and analysis system of important indices.

\subsection{To change functions of the government and to gradually make perfect the system of export of labor service}

Urban and rural labor force resource pool for migrant workers is established according to such aspects as flow of labor force, its quantity, age structure, degree of education and aspiration of employment, etc. We should strengthen guidance to those migrant workers who return to their hometown. For example, we can provide service for migrant workers who start an undertaking when they return their hometown, establish normal information feedback system, lead them to use the capital, skills and experiences accumulated during the period of migrant working to undertake an enterprise in their hometown so as to absorb more people for employment and form a benign running mechanism of export of labor service and starting an undertaking when returning to the hometown.

We should reinforce obligations for training export of labor service that should be assumed by such training institutions as employment training center, etc, and improve the overall quality of workers. We should develop training for specific posts and order training. Considering demands of the market, we should continually adjust design of majors and content of training and broaden new fields of labor service cooperation. By means of various forms, we can apply modernized means of communication to continually open up new fields and channels of export of labor service and to establish cooperative labor relationship with areas in great demand of labor workers. We should set up a normal working mechanism and establish benign labor cooperative relationship. We ought to reinforce different sorts of special fairs, increase the quantity of export of labor service in economically developed regions and improve their quality.

\section{References}

Cai, Fang \& Wang, Dewen. (1999). Sustainability of Economic Growth in China and Its Labor Contributions. Economic Research Journal, (10).

Chen, Yundun \& Chen, Cangming. (2001). Development and Management of Human Capital. China Statistics Press.

Cui, Yuping. (2004). On Contributions of Chinese High Education to Economic Growth. Journal of Beijing Normal University (Social Science), (1).

Feng, Guangming. (2004). Human Capital Investment \& Transformation of Economic Growth Mode. Chinese Journal of Population Science, (1).

Liu, Yingqiu. (1999). On Investment of Human Capital and Its Significance to Economic Growth in China. Management World, (3).

Shen, Lisheng \& Zhu, Yunfa. (1999). Analysis of Human Capital and Economic Growth. China Social Sciences Press.

Tang, Wenying. (2007). Ideological and Political Work and Management of Modern Human Resources Development. Talent Exploration, (7).

Zhao, Qiucheng. (2000). Study on Human Resource Development. Dongbei University of Finance \& Economics Press.

Zhu, Honglin. (2005). On Human Resources Development and Management Innovation in Modern Enterprises. Modern Management Science, (6). 